\title{
MODEL PENGEMBANGAN KELEMBAGAAN PETANI MENUJU KELEMBAGAAN EKONOMI PETANI di KECAMATAN SINDANGKASIH CIAMIS
}

\author{
Lukman Effendy \\ Email : F1515di@gmail.com \\ Prodi Penyuluhan Pertanian Berkelanjutan Politeknik Pembangunan Pertanian \\ (Polbangtan) Bogor \\ Jln. Aria Surialaga Cibalagung, Kota Bogor \\ Riddia Mustofa \\ Email : riddia_mustofa@gmail.com \\ Prodi Penyuluhan Pertanian Berkelanjutan Politeknik Pembangunan Pertanian \\ (Polbangtan) Bogor \\ Jln. Aria Surialaga Cibalagung, Kota Bogor
}

\begin{abstract}
ABSTRAK
Kelompok Tani (KT) Seperti Gapoktan semestikan tumbuh menjadi kelembagaan ekonomi yang berorientasi pasar dan tumbuh menjadi badan usaha atau korporasi. Penelitian yang dilaksanakan pada di Kecamatan Sindangkasih Kabupaten Ciamis pada bulan April sampai dengan Juli 2019. Penelitian ini dimaksudkan untuk mendesain model pengembangan KP menjadi kelembagaan ekonomi petani (KEP). Responden penelitian adalah petani yang tergabung dalam kelompoktani (keltan) dengan komoditas usaha sayuran dataran rendah. Total responden berjumlah 90 orang dari populasi sebanyak 679 yang ditetapkan menggunakan rumus Slovin. pengumpulan data dilakukan melalui wawancara semi terstruktur dengan menggunakan kuesioner tertutup yang telah diuji keterandalannya. Data dianalisis dengan dua cara, yaitu; (1) untuk menggambarkan peubah-peubah penelitian, dilakukan analisis deskriptif, (2) sedangkan untuk mengetahui faktor yang berpengaruh digunakan analisis regresi linier berganda. Hasil analisis enunjukkan bahwa: faktor yang berpengaruh pada pengembangan kelembagaan menjadi KEP adalah faktor keltan, yang terdiri atas keanggotaan, fungsi keltan dan kelas keltan. Untuk merancang strategi pengembangan KT menjadi KEP dimulai dengan meningkatkan fungsi keltan dan meningkatkan karakteristik anggota serta menaikkan kelas keltan.
\end{abstract}

Kata Kunci: Kelembagaan Petani, Kelompok Tani, Kelembagaan Ekonomi Petani

\begin{abstract}
Farmer Group (FG) like Gapoktan must grow into a market-oriented economic institution and grow into a business entity or corporation. The research, which was conducted in April - July 2019 in Sindangkasih Subdistrict, Ciamis Regency was intended to design a model for developing KP into a farmer economic institution (KEP). Research respondents are farmers who are members of farmers groups (FG) with lowland vegetable commodity. A total of 90 respondents from a population of 679 were determined using the Slovin formula. Data collection is done through semi-structured interviews using closed questionnaires that have been tested for reliability. Data were analyzed in two ways, namely; (1) to describe the performance of the research variables, a descriptive analysis was carried out, (2) while to find out the influential factors used multiple linear regression analysis. The analysis result shows that: the factors that influence the institutional development into PEM are the keltan factor, which consists of membership, FG function and keltan class. To design a strategy for developing KT into KEP starting with improving the function of the keltan and increasing the characteristics of members and raising the class of Farmer Group.
\end{abstract}

Keywords: Farmer Institution, Farmer Group, Farmer Economic Institution 


\section{PENDAHULUAN}

Kondisi kelembagaan petani di Indonesia perlu dibenahi. Kondisi ini menyangkut kelembagaan petani seperti; kelompok tani dan gabungan kelompok tani (Gapoktan) yang belum mengarah pada kelembagaan ekonomi petani (KEP). Kelembagaan yang ada sekarang masih berpaku pada produksi dan belum mengarah pada kegiatan pasca produksinya. Hal ini belum sejalan dengan keinginan pemerintah yang menginginkan usahatani yang berskala ekonomi, berorientasi pasar dan berbasis kawasan korporasi.

Kelembagaan Ekonomi Petani sendiri merupakan lembaga yang melaksanakan kegiatan usahatani yang dibentuk oleh dari dan untuk petani, guna meningkatkan produktivitas dan efisiensi usahatani, baik yang berbadan hukum maupun yang belum berbadan hukum (Permentan No. 67, 2016). Namun untuk menginisiasi kelembagaan petani menjadi kelembagaan ekonomi petani, terdapat kendala di antaranya ompetensi sumber daya manusia, dan infrastruktur teknologi yang rendah, akses pembiayaan, kualitas pengelolaan usaha tani, produksi belum memenuhi skala ekonomi, dan pengetahuan manajemen bisnisnya belum profesional.

Kecamatan Sindangkasih merupakan salah satu kecamatan yang ada di Kabupaten Ciamis, terletak di sebelah barat dan berbatasan langsung dengan Kabupaten Tasikmalaya. Terdapat banyak lahan pertanian dengan komoditas pertanian yang beragam. Selain itu banyak pula kelompoktani yang tergabung dalam gabungan kelompok tani (Gapoktan) yang tersebar di sepuluh desa. Dari beberapa gapoktan hanya ada satu koperasi pertanian yang terbentuk, yaitu koperasi petani komunitas sayuran dataran rendah. Namun kondisi koperasi tersebut belum berjalan secara efektif.

Kurang efektifnya koperasi sebagai salah satu bentuk kelembagaan ekonomi pertanian yang ada di Kecamatan Sindangkasih disebabkan belum berbadan hukum, di samping eterbatasan petani mengakses pasar dan kemampuan mengelola koperasi yang belum memadai. Berdasarkan kondisi tersebut diperlukan pengkajian dengan topik "Model Pengembangan Kelembagaan Petani Menjadi Kelembagaan Ekonomi Petani Pada Komunitas Usahatani Sayuran"

Pengkajian ini bertujuan untuk; (1) mendeskripsikan keragaan kelembagaan petani di Kecamatan Sindangkasih, (2) menganalisis faktor-faktor yang mempengaruhi pengembangan kelembagaan petani menjadi kelembagaan ekonomi petani sayuran, dan (3) menemukan model dan strategi pengembangan kelembagaan petani menjadi kelembagaan ekonomi. 


\section{METODE PENELITIAN}

\section{Waktu dan Tempat}

Penelitian ini dilaksanakan selama tiga bulan, April sampai Juli 2019 di beberapa desa Kecamatan Sindangkasih Kabupaten Ciamis. Desa yang terpilih adalah Desa Gunungcupu, Wanasigra dan Budiharja. Pemilihan desa didasarkan pada potensi hortikultura yang paling besar di antara desa yang ada (purposive sampling). Penelitian ini menggunakan metode survei dan observasi langsung di lapangan pada komunitas petani yang berusahatani sayuran dataran rendah.

\section{Populasi dan Sampel}

Populasi dalam pengkajian ini adalah petani anggota kelompok tani berjumlah 679 orang yang diambil dari 3 gapoktan dari setiap desa yang berbeda, kemudian diambil 3 kelompoktani setiap desa. Desa tersebut yaitu Desa Gunungcupu, Wanasigra dan Budiharja. Pemilihan desa didasarkan pada potensi hortikultura yang paling besar di antara esa yang ada (purposive sampling). Kriteria sampel adalah petani anggota kelompok yang berusahatani komoditas sayuran. Adapun rincian sampel setiap kelompok adalah sebagai berikut:

Tabel 1. Jumlah populasi dan sampel penelitian pada setiap kelompok

\begin{tabular}{rllccc}
\hline No & Gapoktan & Kelompok & Populasi & Perhitungan & Sampel \\
\hline 1 & Cupumanik & Berkah Tani & 40 & $(40 / 679) \times 90$ & 5 \\
2 & Cupumanik & Cupumanik I & 120 & $(120 / 679) \times 90$ & 16 \\
3 & Cupumanik & Cupumanik II & 50 & $(50 / 679) \times 90$ & 6 \\
4 & Tani Jaya Utama & Tanijaya I & 67 & $(67 / 679) \times 90$ & 9 \\
5 & Tani Jaya Utama & Tanijaya II & 60 & $(60 / 679) \times 90$ & 8 \\
6 & Tani Jaya Utama & Tanijaya III & 51 & $(51 / 679) \times 90$ & 7 \\
7 & Neureus Utama & Neureus I & 96 & $(96 / 679) \times 90$ & 13 \\
8 & Neureus Utama & Neureus III & 135 & $(135 / 679) \times 90$ & 18 \\
9 & Neureus Utama & Neureus V & 60 & $(60 / 679) \times 90$ & 8 \\
\hline \multicolumn{7}{r}{} & Total & 679 & & 90 \\
\hline
\end{tabular}

\section{Data dan Pengumpulan Data}

Data yang dikumpulkan terdiri dari data primer dan data sekunder. Data primer merupakan data yang diperoleh langsung dari sumbernya yaitu petani dan penyuluh setempat, yang dikumpulkan menggunakan instrumen berupa daftar pertanyaan (kuesioner), melalui wawancara semi terstruktur, sedangkan data sekunder adalah data yang relevan dengan penelitian yang diambil 3 kelompok tani setiap desa.

Instrumen yang digunakan dalam pengkajian ini berup kuesioner ertutup yang telah dipersiapkan berupa pernyataan dan pertanyaan dengan skor jawaban 1 sampai 4. Untuk 
menguji kesahihan dan keterandalan kuesioner, terlebih dahulu dilakukan uji validitas dan reliabilitas dengan cara memberikan kuesioner kepada petani yang bukan dijadikan responden sebanyak 15 orang.

Data hasil pengisian kuesioner tersebut kemudian diolah dengan menggunakan program Statistical Package for the Social Sciences (SPSS) 20. Butir pertanyaan akan dinyatakan valid apabila ' $r$ ' hitung lebih besar dari ' $r$ ' tabel (0,514). Hasilnya dari 57 butir pertanyaan yang disusun ada 9 butir pertanyaan dinyatakan tidak valid, dan kemudian diperbaiki. Sementara hasil uji reliabilitas diperoleh nilai alpha cronbach's $>0.700$, dan menurut Arikanto (2010) ketika nilai cronbach's Alpha > 0,600 maka instrument tersebut termasuk andal dan mantap sehingga layak digunakan sebagai alat pengumpulan data.

\section{Analisis Data}

Analisis data yang digunakan dalam pengkajian ini adalah analisis statistik deskriptif dan analisis regresi dengan bantuan program Statistical Product and Service Solutions (SPSS) versi 20. Analisis statistik deskriptif adalah untuk mendeskripsikan atau memberi gambaran keragaan kelembagaan petani (kelompok tani dan gapoktan). Sementara untuk mengetahui faktor yang mempengaruhi pengembangan kelembagaan petani menjadi kelembagaan ekonomi, dilakukan analisis regresi linier berganda. Untuk mempermudah analisis, data yang terkumpul terlebih dahulu ditabulasi sesuai dengan variabel dan indikator masing-masing. Adapun rumus persamaan garis regresi linear berganda adalah sebagai berikut: $\quad \boldsymbol{Y}=\boldsymbol{a}+\boldsymbol{b}_{1} \boldsymbol{X}_{1}+\boldsymbol{b}_{2} \boldsymbol{X}_{2}$

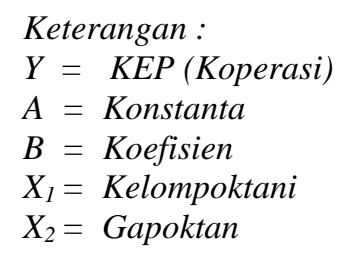

\section{HASIL DAN PEMBAHASAN}

\section{Keragaan Kelembagaan Petani}

Berdasarkan hasil wawancara dan penelusuran dokumen programa kecamatan yang ada di Kecamatan Sindangkasih, di Desa Cupumanik terdapat 11 kelompoktani, Desa Budiharja 10 kelompoktani dan Desa Wanasigra 8 kelompoktani. Rata-rata semua kelompoktani yang ada tergolong kelas lanjut. Setiap kelompoktani yang ada tergabung kedalam gapoktan yang ada di desa masing-masing. Untuk Desa Gunungcupu gapoktan yang ada bernama Cupumanik, di Desa Budiharja ada gapoktan Tani Jaya Utama dan di Wanasigra bernama gapoktan Neureus Utama. 
Dalam pengkajian ini, yang termasuk ke dalam keanggotaan adalah; umur, tingkat pendidikan formal, luas lahan dan lama keanggotaan dalam kelompoktani. Secara rinci keanggotaan tersaji dalam tabel berikut:

Tabel 2. Karakteristik Responden

\begin{tabular}{|c|c|c|c|}
\hline No & Indikator & Jumlah (orang) & Persentase (\%) \\
\hline \multirow[t]{5}{*}{1} & Umur & & \\
\hline & $\overline{<44 \text { th }}$ & 20 orang & 22.2 \\
\hline & 44 th -51 th & 22 orang & 24.4 \\
\hline & 52 th -63 th & 24 orang & 26.6 \\
\hline & $>63$ th & 26 orang & 28.8 \\
\hline \multirow[t]{5}{*}{2} & Pendidikan & & \\
\hline & 0 th & 35 orang & 38,9 \\
\hline & 6 th & 39 orang & 43,3 \\
\hline & 9 th & 16 orang & 15,6 \\
\hline & 12 th & 2 orang & 2,2 \\
\hline \multirow[t]{5}{*}{3} & Luas Lahan & & \\
\hline & $<1680 \mathrm{~m}^{2}$ & 16 orang & 17,8 \\
\hline & $1680 \mathrm{~m}^{2}-4200 \mathrm{~m}^{2}$ & 29 orang & 32,2 \\
\hline & $4300-9300 \mathrm{~m}^{2}$ & 22 orang & 25,4 \\
\hline & $>9300 \mathrm{~m}^{2}$ & 23 orang & 25,6 \\
\hline \multirow[t]{5}{*}{4} & Lama Keanggotan & & \\
\hline & $<5$ tahun & 13 orang & 14,4 \\
\hline & 6 tahun -7 tahun & 25 orang & 27,8 \\
\hline & 8 tahun -9 tahun & 23 orang & 25,6 \\
\hline & $>9$ tahun & 29 orang & 32,2 \\
\hline
\end{tabular}

Tabel 2 di atas menunjukkan bahwa umur responden ang paling banyak $(28,8 \%)$ adalah berumur $>63$ tahun, lamanya menempuh pendidikan sebagian besar $(43 \%)$ ada pada angka 6 tahun, memiliki luas lahan sebagian besar (32,2\%) berkisar antara $1680 \mathrm{~m}^{2}-4200 \mathrm{~m}^{2}$, dan lama keanggotaan responden dalam kelompoktani sebagian besar $(32,2 \%)$ berada pada angka $>9$ tahun.

Persentase umur didominasi oleh responden >63 tahun memang berdasarkan temuan, banyak petani yang sudah tua. Kurangnya regenerasi petani menjadi salah satu penyebabnya. Untuk aspek pendidikan yang dikategorikan rendah disebabkan karena memang dulu pendidikan bukan prioritas. Responden lebih memilih bekerja daripada menghabiskan waktu untuk menempuh pendidikan. Kemudian luas lahan yang ada cenderung sempit karena didominasi oleh responden dengan lahan $1680 \mathrm{~m}^{2}-4200 \mathrm{~m}^{2}$. Dari luasan yang ada, dibagi lagi untuk tanaman pangan, palawija dan hortikultura. Lalu lama keanggotaan didominasi pada angka >9 tahun karena memang petani sudah lama tergabung dalam kelompok, bahkan ada yang sejak kelompok tersebut terbentuk.

Kelompok tani merupakan variabel yang diindikasikan mempunyai pengaruh terhadap perubahan kelembagaan petani menjadi kelembagaan ekonomi petani. Kelompok tani 
mencakup keanggotaan, fungsi kelompok dan kelas kelompok. Secara rinci dapat dilihat pada grafik di bawah ini :

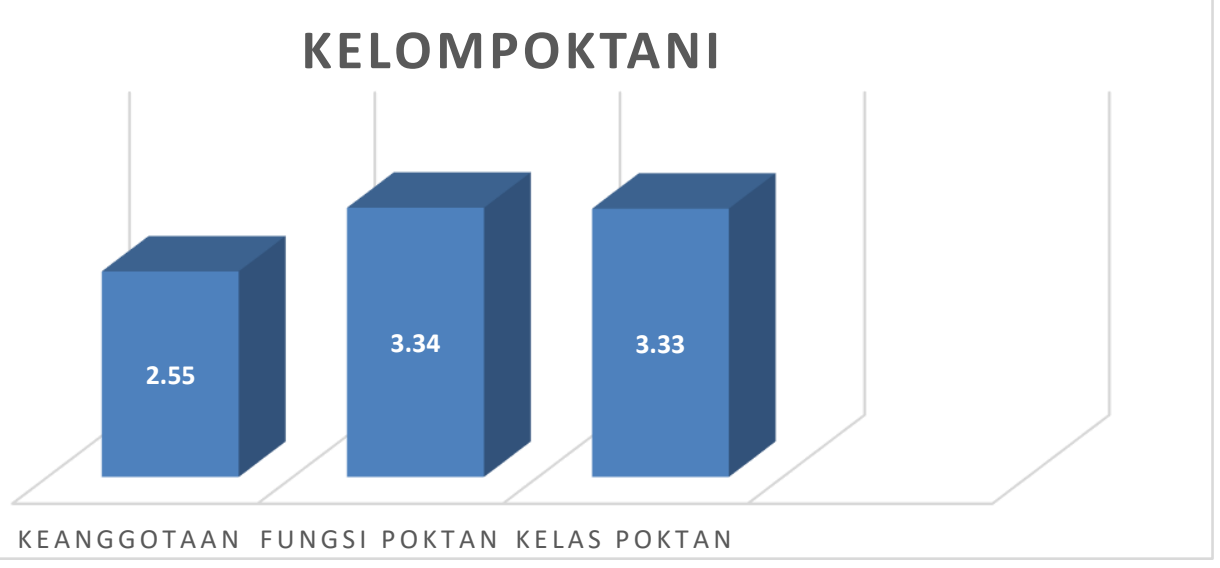

Gambar 2. Keragaan Kelompok tani

Grafik di atas menunjukkan bahwa skor tertinggi diperoleh dari aspek fungsi kelompok sebesar 3,34 dan nilainya berdekatan dengan skor rata-rata kelas kelompoktani yaitu 3,33. Artinya kedua aspek tersebut memberikan pengaruh yang besar dalam perolehan skor variabel kelompoktani sedangkan skor terendah diperoleh dari aspek keanggotaan dengan skor 2,55. Aspek keanggotaan mencakup karakteristik anggota atau responden dalam pengkajian.

Sebagian kelompoktani sudah menjalankan fungsi kelompok dengan cukup baik. Ada pertemuan rutin sebagai bentuk kelas belajar, saling bekerja sama dalam memecahkan masalah dan mempunyai usahatani sebagai wujud fungsi unit produksi. Meskipun kelompok yang ada rata-rata hanya tergolong kelas lanjut.

Gabungan Kelompoktani atau gapoktan terdiri dari unit sarana dan prasarana produksi, unit produksi, unit usaha pengolahan, unit usaha keuangan mikro, unit usaha pemasaran, unit penyedia informasi. Rata-rata skor yang diperoleh dapat dilihat dari tabel berikut:

\section{GABUNGAN KELOMPOKTANI}

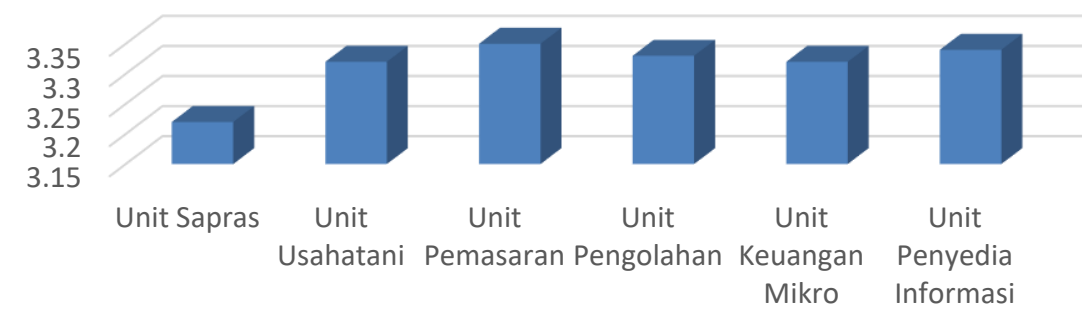

Gambar 3. Keragaan Gabungan Kelompoktani 
Garfik di atas menunjukkan bahwa skor rata-rata dari setiap aspek menunjukkan nilai yang hampir sama, dengan selisih yang kecil antar aspek. Tetapi untuk skor tertinggi diperoleh dari aspek unit usaha pengolahan sebesar 3,35, sedangkan skor terendah yaitu diperoleh dari aspek unit sarana dan prasarana dengan skor 3,22. Unit-unit usaha yang ada pada fungsi gapoktan memang belum dijalankan oleh semua gapoktan yang ada di Kecamatan Sindangkasih. Hal ini berdasarkan fakta di lapangan bahwa gapoktan memang belum berperan aktif dalam kegiatan usahatani yang dijalankan petani. Meskipun nilai yang ditunjukkan dari hasil kuesioner termasuk tinggi, namun fakta di lapangan berbeda.

\section{Koperasi}

Dalam variabel koperasi, yang menjadi aspek atau indikatornya adalah mengenai prinsip-prinsip koperasi berdasarkan UU No. 25 tahun 1992. Secara rinci dapat dilihat pada tabel berikut :

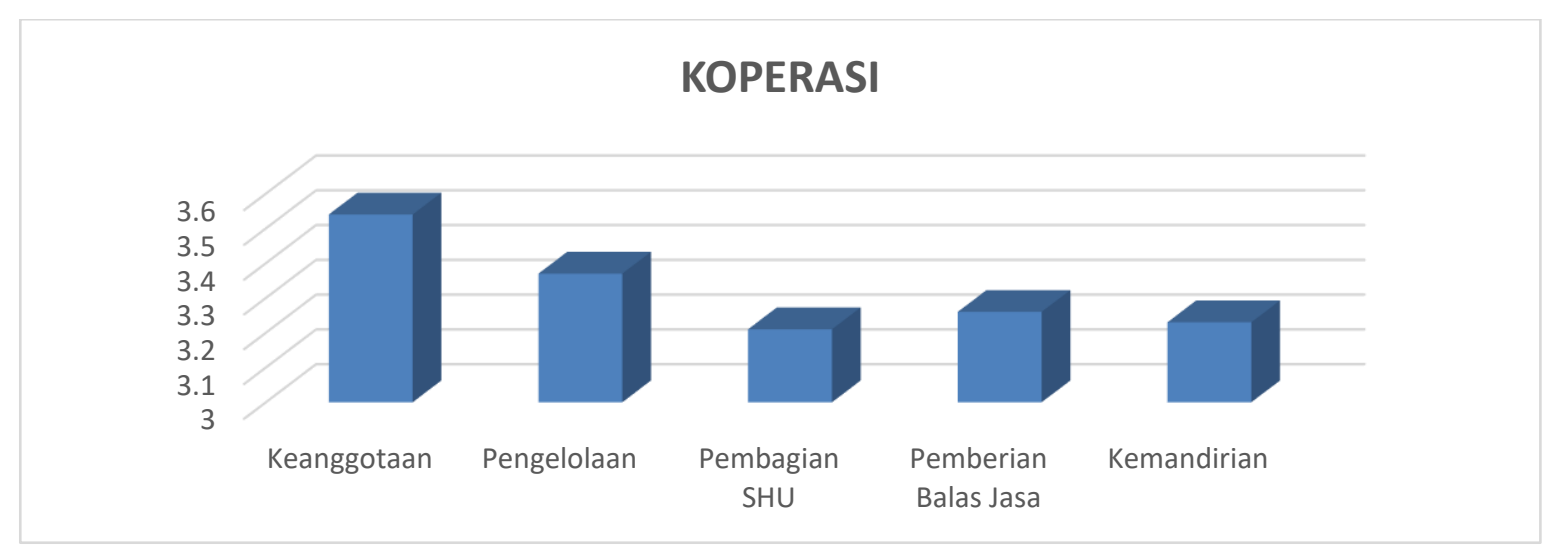

Gambar 4. Keragaan Kelembagaan Ekonomi Petani (Koperasi)

Grafik di atas menunjukkan data hasil dari rata-rata skor variabel koperasi (Y) yang diperoleh responden. Jika dirata-ratakan nkor variabel koperasi (Y) tergolong kategori tinggi dengan skor 3,34. Aspek keanggotaan menjadi aspek yang paling tinggi dengan rata-rata 3,54 sedangkan aspek pembagian sisa hasil Usaha (SHU) mendapat kan skor ratarata terendah yaitu 3,21. Berdasarkan hasil temuan di lapangan responden memang sudah mengetahui prinsip-prinsip koperasi. Akan tetapi baru sekedar tahu dan belum diterapkan. Tetapi ada satu kelompok yang memang sudah tahu dan dalam menjalankan usahataninya ada prinsip koperasi yang dijalankan.

\section{Pengaruh Kelompoktani dan Gapoktan terhadap Kelembagaan Ekonomi Petani}

Untuk mengetahui pengaruh dari setiap variabel $\mathrm{X}$ yang dipilih terhadap variabel $\mathrm{Y}$ maka dilakukan analisis regresi. Dari analisis regresi, didapatkan nilai koefisien determinasi atau $\mathrm{R}^{2}$ sebesar 0,321 , yang artinya bahwa variabel yang dipilih hanya 
berpengaruh sebesar 30\%, sisanya dipengaruhi oleh faktor lain di luar variabel, yang tidak ada dalam pengkajian ini. Hasil analisis dapat dilihat pada tabel erikut :

Tabel 4. Hasil analisis regresi

\begin{tabular}{clccc}
\hline No. & \multicolumn{1}{c}{ Peubah } & Nilai & Signifikansi & Keterangan \\
\hline 1 & Konstanta & 1.833 & 0,000 & Signifikan/sangat nyata \\
2 & Kelompok Tani $\left(\mathrm{X}_{1}\right)$ & 0.438 & 0,000 & Signifikan/sangat nyata \\
3 & Gapoktan $\left(\mathrm{X}_{2}\right)$ & 0.029 & 0,733 & Tidak Signifikan/tidak nyata \\
\hline
\end{tabular}

Hasil analisis tersebut diperoleh bahwa pengaruh variabel kelompoktani dan gabungan kelompoktani atau gapoktan terhadap kelembagaan ekonomi petani koperasi adalah $\boldsymbol{Y}=$ $(\mathbf{1}, 833)+(\mathbf{0 , 4 3 8}) \boldsymbol{X}_{1}+(\mathbf{0 , 0 2 9}) \boldsymbol{X}_{2}$, yang artinya bahwa kelompoktani $\left(\mathrm{X}_{1}\right)$ memberikan kontribusi pengaruh sebesar 0,438 dan gabungan kelompoktani sebesar 0,029.

Hasil ini mengindikasikan, bahwa apabila kelompoktani $\left(\mathrm{X}_{1}\right)$ dan gabungan kelompoktani $\left(\mathrm{X}_{2}\right)$ bernilai nol (0), maka koperasi pertanian (Y) akan positif 1,833. Selanjutnya dapat diuraikan bahwa nilai koefisien $\boldsymbol{b}_{\boldsymbol{1}}$ adalah sebesar 0,438 yang menjelaskan pengaruh kelompoktani terhadap koperasi pertanian. Artinya jika gabungan kelompoktani $\left(\mathrm{X}_{2}\right)$ adalah konstan, maka setiap kenaikan nilai kelompoktani $\left(\mathrm{X}_{1}\right)$ sebesar satu akan meningkatkan koperasi pertanian (Y) sebesar 0,438 satuan. Selanjutnya nilai koefisien $\boldsymbol{b}_{2}$ adalah 0,029 , yang menunjukan pengaruh gabungan kelompoktani $\left(\mathrm{X}_{2}\right)$ terhadap koperasi pertanian (Y). Artinya jika kelompoktani $\left(\mathrm{X}_{1}\right)$ adalah konstan atau tetap, maka setiap kenaikan nilai gapoktan $\left(\mathrm{X}_{2}\right)$ sebesar satu satuan akan meningkatkan koperasi pertanian (Y) sebesar 0,029 satuan.

\section{Pengaruh Kelompoktani terhadap Kelembagaan Ekonomi Petani}

Berdasarkan analisis regresi, dapat dinyatakan bahwa kelompoktani memberikan pengaruh yang nyata atau signifikan $(\mathrm{p} \leq 0.05)$ terhadap pengembangan kelembagaan petani menjadi kelembagaan ekonomi petani, dengan nilai koefisien yang ditunjukkan sebesar 0,438. Dengan nilai koefisien tersebut kelompotani dapat mendorong pengembangan kelembagaan petani menjadi kelembagaan ekonomi apabila ditingkatkan, terutama dalam aspek fungsi kelompok.

Variabel kelompoktani berpengaruh cukup besar dalam pengkajian ini didukung dengan fakta yang ada di lapangan sebagian besar kegiatan usahatani masih terfokus di kelompoktani. Di salah satu desa bahkan sudah ada kelompok yang sudah menjalankan usaha tani dengan sistem menyerupai koperasi. Ada pemupukan modal melalui laba atau keuntungan yang diputar, ada simpan pinjam, pembagian komoditas, sampai pemasaran melalui kelompok. Hal ini menjadi modal yang baik untuk nantinya kelembagaan petani dikembangkan menjadi kelembagaan ekonomi. 


\section{Pengaruh Gabungan Kelompoktani terhadap Kelembagaan Ekonomi Petani}

Hasil analisis regresi untuk variabel gabungan kelompoktani menunjukkan bahwa gabungan kelompoktani berpengaruh namun tidak nyata $(\mathrm{p} \leq 0.05)$ terhadap pengembangan kelembagaan petani menjadi kelembagaan ekonomi petani, dengan koefisien pengaruh sebesar 0,029. Dengan nilai koefisien tersebut maka gabungan kelompoktani dapat memberikan pengaruh terhadap pengembangan kelembagaan petani menjadi kelembagaan ekonomi ketika ditingkatkan, terutama dalam aspek unit usaha pengolahan. Namun pengaruh yang diberikan sangat sedikit. Hal ini didukung dengan ketidakaktifan gapoktan di lapangan. Belum ada kegiatan yang menyangkut unit usaha tani yang berhubungan dengan fungsi gapoktan itu sendiri.

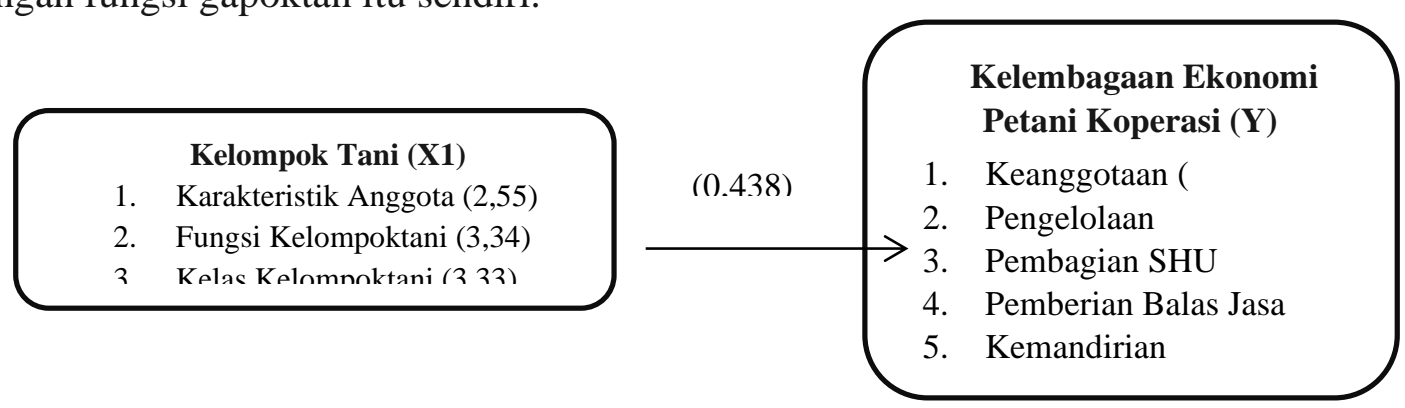

Gambar 5. Model Pengembangan Kelompok Tani menjadi KEP

Berdasarkan hasil analisis, untuk meningkatkan pengembangan kelembagaan petani maka dimulai dengan : (1) kelompoktani (X1) yaitu dengan mempertahankan fungsi kelompoktani dan meningkatkan karakteristik anggota melalui kegiatan penyuluhan, pelatihan dan pendidikan. Kemudian untuk kelas kelompoktani dapat dilakukan penyuluhan tentang dinamika kelompok, peningkatan kapasitas kelompoktani dan penilaian kelas kelompok secara berkala.

\section{KESIMPULAN}

1) Sebagian besar petani termasuk kategori usia produktif dengan kisaran umur $44-63$ tahun (51.00\%), tingkat pendidikan Sekolah Dasar (43.30\%), luas kepemilikan lahan usahatani sebesar $1.700 \mathrm{~m} 2-4.200 \mathrm{~m} 2$ (32.20\%), dan menjadi anggota dalam kelompok relatif lama, lebih dari 9 tahun (32.20\%).

2) Faktor kelompoktani $\left(X_{1}\right)$ memberikan pengaruh yang signifikan terhadap pengembangan kelembagaan petani menjadi kelembagaan ekonomi petani dengan koefisien pengaruh sebesar 0,438 ( $\mathrm{p}<0.001)$. Sedangkan gapoktan $\left(\mathrm{X}_{2}\right)$ memberikan pengaruh yang tidak signifikan dengan koefisien pengaruh sebesar 0,029 ( $p>0.005)$. 
3) Dalam penyusunan model pengembangan kelembagaan petani menjadi kelembagaan ekonomi petani, dapat dimulai dengan mempertahankan fungsi kelompok tani, kemudian meningkatkan kelas kelompok dan keanggotaan pada variabel kelompoktani (X1).

\section{SARAN}

1) Perlu dikaji ulang terkait dengan gapoktan yang tidak memberikan pengaruh nyata terhadap pengembangan Kelembagaan Petani menjadi Kelembagaan Ekonomi Petani.

2) Perlu dilakukan penelitian serupa dengan memilih lokasi yang berbeda pada komunitas usahatani yang sama.

\section{DAFTAR PUSTAKA}

Arikunto, S. 2010. Prosedur Penelitian Suatu Pendekatan Praktik. Jakarta: PT. Rineka Cipta.

Effendy, L. 2009. Kinerja Petani Pemandu dalam Pengembangan PHT dan Dampaknya pada Perilaku Petani di Jawa Barat. Bogor: Disertasi Pascarajana IPB

Effendy, L dan Dinia, S.P. 2018. Tingkat Adopsi Teknologi Sistem Jajar Legowo Padi Sawah di Kecamatan Cigasong Kabupaten Majalengka. Bogor: Karya Ilmiah Penugasan Akhir STPP.

Hendrojogi. 2012. Koperasi Asas-Asas, Teori dan Praktik. Jakarta. PT. Raja Grafindo Persada.

Husein Umar. 2004. Metode Penelitian Untuk Skripsi Dan Tesis Bisnis, Cet ke 6, Jakarta : PT. Raja Grafindo Persada.

Masitah, Hesti Dwi., Made Narka Tenaya, dan Dwi Putra Darmawan. 2016. Strategi Pemberdayaan Koperasi Tani Berbasis Agribisnis di Kabupaten Badung (Studi Kasus pada Koperasi Subak Uma Lambing). Jurnal Manajemen Agribisnis. Vol. 4 No. 2. Hal. 91-110.

Permentan Nomor 67 Tahun 2016 Tentang Pembinaan Kelembagaan Petani. Kementerian Pertanian, Jakarta.

Pusluhtan. 2015. Petunjuk Pelaksanaan Penumbuhan dan Pengembangan Kelembagaan Ekonomi Petani Tahun 2016.

Undang-Undang Republik Indonesia Nomor 16 tahun 2006 tentang Sistem Penyuluhan Pertanian, Perikanan dan Kehutanan.

Undang-Undang Nomor 25 tahun 1992 tentang Perkoperasian. DIH Kementerian Keuangan, Jakarta.

WCED. 1987. World Commission on Environment and Development (Our Common Future). Oxford University Press, Oxford. 